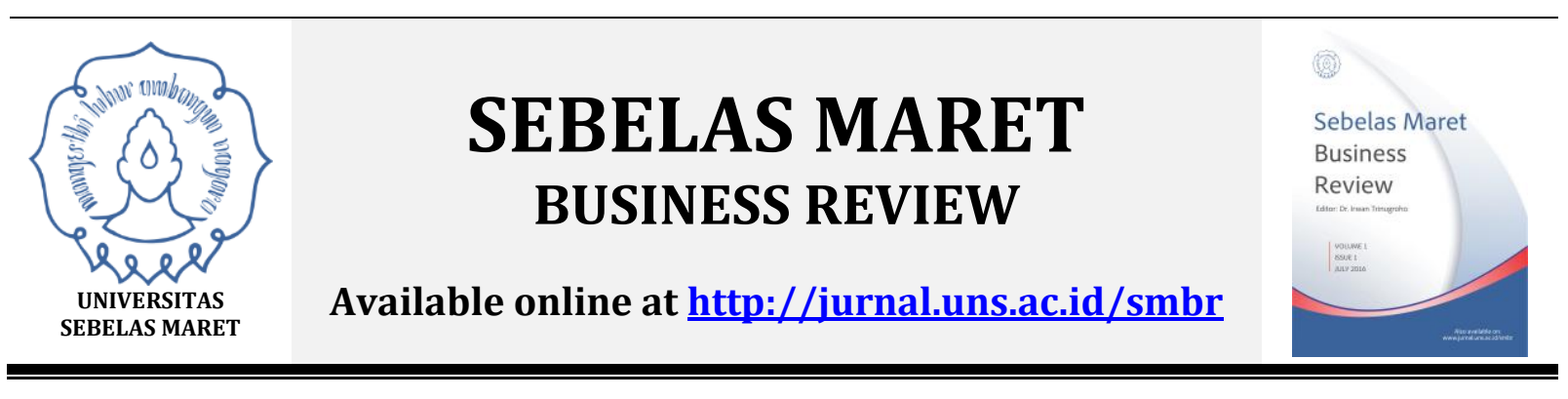

\title{
Redesigning Independent Community Empowerment Model For Household Craftsmen
}

\section{Agus Utomo' ${ }^{\text {, Anwar Hamdani'2, Riyanto }}{ }^{3}$, and I Gusti Putu Diva Awatara ${ }^{4}$}

\author{
STIE Adi Unggul Bhirawa, Surakarta, Indonesia \\ 1Email : agu utomo@yahoo.co.id,2Email : anwar aub@yahoo.co.id, \\ ${ }^{3}$ Email : riyanto aub15@yahoo.co.id, 4Email : gruppe cemara@yahoo.co.id
}

\begin{tabular}{l} 
ARTICLE INFO \\
\hline Article History: \\
Received 25 February \\
2017 \\
Received in Revised Form \\
Accepted 17 May 2017 \\
Available online 30 May \\
2017
\end{tabular}

Keywords:

Redesigned Model, Small Business, Household Craftsmen

\section{ABSTRACT}

Redesigning the model of independent community empowerment program can be performed by (1) reviewing the factors to develop independent empowerment for household craftsmen in Surakarta, (2) identifying various government policy that support the development of household craftsmen's independency in Surakarta, and (3) formulate the redesigned model of independent community empowerment for household craftsmen in Surakarta. The subject of this study is household craftsmen in Surakarta, Central Java Province. This study is a research and development type, started with survey and need assessment for developing craftsmen's independency in entrepreneurship based on community's characters and values, media to implement the proposed model, action, and evaluation. This study will be conducted in Banjarsari sub-district in Surakarta municipality. Observation, interview, demonstration, and simulation will be employed in this study to collect the data. The data will be analyzed using mixed technique between descriptive and quantitative technique. Through FGD we will formulate the concept of redesigned model for developing independent community empowerment for household craftsmen. In this study we have collected the data on the potency of studied area; the data on the 


problems and supporting factors for the implementation of
household craftsmen's independency development
program, (2) the data on the number of prevalent
entrepreneurs, (3) performing need assessment of
household craftsmen in Surakarta, which will enable us to
formulate the redesigned model of independent
community empowerment for household craftsmen. The
final aim of this study is applying the redesigned model of
independent community empowerment for household
craftsmen in order to achieve entrepreneurs' business
independency.

\section{INTRODUCTION}

Since 2008, PNPM Mandiri function is expanded by including the Program of Regional Socio-Economic Infrastructure Development to integrate the center of economics growth with its surrounding area. PNPM Mandiri is strengthened with various community empowerment programs implemented by various departments/sectors and local government. The implementation of PNPM Mandiri in 2008 also takes place in the underdeveloped villages. By integrating various programs of community empowerment into PNPM Mandiri policy, it is expected that poverty alleviation program will be more effective and efficient.

Government plans that the process of community empowerment under PNPM Mandiri program is implemented at latest in 2015. This is in line with the deadline target for achieving Millennium Development Goals (MDGs). PNPM Mandiri implementation based on the measured indicator will assists Indonesia in achieving the MDGs target. Based on this background, PNPM Mandiri as one of government's programs in alleviating poverty needs an analysis on how this program is implemented in an area in Indonesia. This study will be focused on how stakeholders take roles in formulating the program, because in this program, community is no longer an object of poverty alleviation program but a subject of poverty alleviation program in their area.

This study is conducted in Surakarta municipality, Central Java province. Surakarta is selected for several reasons: (1) Surakarta is considered as an area that successfully implement PNPM Mandiri program, (2) villages in Banjarsari subdistrict, geographically located in a unique location; in this sub-district, there are villages located near to Balapan railway station and Tirtonadi bus station, which is well known for its household handicrafts.

\section{LITERATURE REVIEW}

Empowerment has become a mainstream concept in international development but lacks clear definition, which can undermine development initiatives aimed at strengthening empowerment as a route to poverty reduction (Hennink et al, 2012). Empowerment has become a mainstream concept in 
international development (Kabeer 2001), yet the term empowerment still lacks clear definition in this field. This is clearly evidenced by the wide variation in terminology, conceptualisation and meaning used to frame and understand empowerment in the development literature (Hui et al, 2004). This lack of clarity can undermine the value of efforts aimed at strengthening empowerment as a route towards improving community development and poverty reduction. The present article focuses on understanding how international development organisations define and implement empowerment initiatives. Understanding both the conceptual definition of empowerment and its practical application in development initiatives provides us with a clearer perspective from which to define empowerment, its components and complex meaning, and strengthen community initiatives that foster empowerment as a mechanism towards development. Community empowerment approach has been applied through various activities in sectoral and regional development

Hess et al (2002) state that community empowerment is an effort to create/improve community capacity to achieve independency in the development; from, by, and for the community. Barrett \& Usui (2002) to help communities capable of maintaining community sustainable growth, the theory of grass roots democracy emphasizes on the importance of local self-government by employing a bottom-up citizen participating approach for gathering community and for forming stronger attachment.

Generally, PNPM Mandiri aims to improve community welfare and increase job opportunity. The implementation of this program is supported with funding sources from APBN and APBD in the form of cost sharing system. Sub-district becomes the focus of this program to synchronize the planning, implementation, and controlling of the program. Each sub-district is given authority to manage 900 million up to Rp 3 billion rupiah funds. The implementation of the program is fully under the responsibility and authority of Activities Management Unit. Local government is not directly involved in the implementation of the program because PNPM is an empowerment program that is purely from, by, and for the community, thus there is a concern that if government involved in its implementation, there will be a conflict of interest.

Tangkilisan (2003) states that PNPM is the extension of Sub-district Development Program started in 1998. Firstly, the program is only implemented in several sub-districts as a trial, however because government considered this program has succeeded in reducing poverty, they develop this program into national program known as PNPM in all provinces in Indonesia.

Diaz et al (2009) state that community empowerment is an effort to create and improve community capacity, both individually and collectively, to solve various problems related to the improvement of quality of life, independency, and welfare. Community empowerment needs high involvement from government apparatus and other parties to provide opportunity and to ensure the sustainability of the results achieved.

Laverack \& Wallerstein (2001) states that community empowerment process is performed through: first, community development. Community development components consist of a series of activities to build critical awareness and community independency, which consists of mapping for community potency, 
problems, and needs; participatory planning, organizing, utilizing resources, supervisory, and preservation of achieved goals. Second, to support the series of activities, government provides funds to support community learning process, and facilitator, capacity development, mediation, and advocation. Facilitator has important role, especially in the initial stage of empowerment, while volunteers are the main driving force for the community around them.

Third, direct aids for community. Direct Aids for Community component is stimulant funds provided for community to fund several activities planned by the community in an effort to improve their welfare. Fourth, the improvement of government capacity as local executor. This component is a series of activities to improve the capacity of local government and local executors/concerned groups to achieve favorable condition and positive synergy for the community, especially for the group to get a proper life. The activities in this component consist of seminar, training, workshop, and selectively performed field trip, etc. Fifth, aids for Program Management and Development. This component consists of activities to support government and other concerned groups in managing activities such as management consultant, quality control, evaluation, and program development.

While approach or rational efforts in achieving the goals of the program by considering program management principles is the definition of community based development, which can be achieved through: first, utilizing sub-district as locus program to harmonize the planning, implementation, and controlling of the program. Second, put the community in the policy maker position and main player in the local development. Third, prioritize universal values and local culture in the participative development. Fourth, using community empowerment approach that fit with social, cultural, and geographical characteristics. Sixth, through empowerment process that consists of education, independence, and sustainability.

Building household craftsmen independency in Surakarta is affected by supporting factors and constraints. The supporting factors in developing local entrepreneurship in Surakarta consist of: (1). government policy that supports entrepreneurship, (2) educator/researcher/professionals who concerned with entrepreneurship; (3) growing number of entrepreneurs; and (4) the community that has entrepreneurship culture (Hurst \& Pugsley, 2011). While the constraints are: (1) low perception on entrepreneurship; (2) low productivity, human resource, etc.; and (3) minimum access and assets. Further, the aim of development framework is to manage household craftsmen independence in Surakarta. The targets of the development are: (1) increase regional GDP; (2) decrease unemployment; (3) decrease social gap level; (4) improving taqwa, etc.

The constraints in developing entrepreneurship culture also exist in the university environment. University graduates tend to be reluctant in becoming entrepreneurs because they still believe in myths. These myths are: (1) entrepreneurs need capital; (2) entrepreneurs are born, not created; (3) entrepreneurs always an inventor; (4) entrepreneurs are actors, not thinkers; (5) entrepreneurs need good luck; (6) entrepreneurs have to fit with entrepreneurs' profile; (7) entrepreneurs disregard enjoyment; (8) entrepreneurs are people who are awkward in academics and social world; (9) entrepreneurs seek for success but experience shows high level of failures (Hurst \& Lusardi, 2014). 
This study aims to find a way to build independency for household craftsmen in Banjarsari sub-district, Surakarta municipality. The point is how the potency of entrepreneurship can be developed to meet the need of household craftsmen, so that they can become competitive. This final objective can be achieved if there are four main parties who work in synergy and fill each other's shortcomings. These four main parties are: clean and charismatic government, professional researchers and intellectuals who use their research result to build their people, certain number of entrepreneurs, and disciplined and well-performed community members.

Logically, as a firm grows, its resources and capabilities develop, and so the practice of workplace learning should also advance in terms of structure and delivery. However, for SMEs which often rely on informal learning (e.g. Mazzarol, 2003; Ellinger and Cseh, 2007; Saru, 2007; Marsick, 2009), their learning practices - whether they develop with growth or not - are still under-researched. Among very few previous studies, Rutherford et al (2003), Jones's (2004), and Kotey and Sheridan's (2004) may be the closest references, which compare human resource management (HRM) practices (including training) in SMEs between growth stages. Rutherford et al. (2003) discuss how SMEs' training, compensation and recruitment problems vary over four stages (no-growth, low-growth, moderategrowth and high-growth). Jones (2004) points to studying the differences in managers' qualifications and training provisions (methods, fields and providers) across low, moderate and high-growth SMEs. Kotey and Sheridan (2004) consider how HRM practices (recruitment, training methods, performance appraisal, and HRM documentation) of small firms change with firm size (classified as micro, small or medium firms).

Chang (2007) evaluated community empowerment programs in Taiwan's rural agricultural areas, through conducting 189 interviews from 50 different villages. He found that rural communities with better ability of self-governance are usually supported by local economic development and well-planned organizations hosting a variety of empowerment programs. Tseng (2009) found that people living in those urban edge neighborhoods characterized with lower living cost, diverse background, and blue-collar workers tended to have a weaker SOC, according to his study on Taiwan's 72 communities.

Research on his concern and effort to develop independency of household craftsmen in Makamhaji, has been widely performed by government, private sectors, and banking sector. Nelu (2014) they offer various programs related to entrepreneurship. It marks the increase in these parties concern on the entrepreneurship development. The agenda to build independent soul and competence for household craftsmen consist of the following aspects: training, regulation, human resource, capital, funding, etc.

\section{RESEARCH METHOD}

This study is an exploratory study, implementing Borg \& Gall (1989) model. The subject of this study is household craftsmen in Banjarsari sub-district, Surakarta municipality; government apparatus (Cooperative Agency, Industry and Trade Agency, and The Head of Surakarta Municipality Agencies) related with household 
craftsmen, universities, various non-governmental organization, and association of household craftsmen in Surakarta. This study will be performed in Banjarsari subdistrict, Surakarta municipality. This area is selected because based on preliminary study there are large number of local crafters who need assistance. The data and methods used to collect the data are as follows: need assessment questionere, observation and depth interview.

\section{RESULTS AND DISCUSSION}

From need assessment result on household craftsmen in Banjarsari sub-district, Surakarta municipality as an overview of Small and Medium Enterprises (SME) in the research area, we perform descriptive analysis to assess the empowerment level on the small industries. The assessment is performed through several highly important aspects to show craftsmen's empowerment level. These aspects are: production, distribution, market demand, and socio-cultural.

\section{1). Production Capacity}

The level of production capacity is presented in table 1.

Table 1.

Production Capacity

\begin{tabular}{|c|c|c|}
\hline \multirow{2}{*}{ Production Aspect } & \multicolumn{2}{|c|}{ Percentage of Production capacity } \\
\hline & Percentage & Note \\
\hline \multicolumn{3}{|l|}{ Raw Materials } \\
\hline High stock of raw materials & $76.50 \%$ & \multirow[t]{4}{*}{ Very high } \\
\hline Accessibility & $81.60 \%$ & \\
\hline Low price of raw materials & $78.50 \%$ & \\
\hline Average & $78.90 \%$ & \\
\hline \multicolumn{3}{|l|}{ Human Resources } \\
\hline $\begin{array}{l}\text { Availability of human } \\
\text { resources }\end{array}$ & $45.70 \%$ & \multirow[t]{4}{*}{ Low } \\
\hline Low human resource cost & $35.60 \%$ & \\
\hline Ease in skill upgrade & $41.60 \%$ & \\
\hline Average & $40.90 \%$ & \\
\hline \multicolumn{3}{|l|}{ Capital } \\
\hline Need high capital & $54.60 \%$ & \multirow[t]{4}{*}{ Low } \\
\hline Availability of capital & $30.70 \%$ & \\
\hline Accessibility of capital & $41.70 \%$ & \\
\hline Average & $42.33 \%$ & \\
\hline \multicolumn{3}{|l|}{ Technology } \\
\hline Simple technology & $52.60 \%$ & \multirow[t]{4}{*}{ Low } \\
\hline Availability of equipments & $32.80 \%$ & \\
\hline Affordable price of equipment & $38.80 \%$ & \\
\hline Average & $41.40 \%$ & \\
\hline
\end{tabular}

Source: Processed Primary Data 2016

From the table we can describe the following explanation: 


\section{a) Raw Materials Aspect}

The availability of raw materials, can be explained from raw materials stock dimension, in which $76.5 \%$ respondents state that they have ability to fulfill their raw materials need; from the accessibility dimension, 8.60\% respondents state that raw materials are very easy to find; from raw materials price, $78.50 \%$ respondents state that raw materials price are affordable. From this information, we can conclude that: $78.90 \%$ respondents can fulfill their need of raw materials. Thus, raw material dimension has very high score, or we may consider that entrepreneurs are highly capable to fulfill their need in raw materials.

b) Human Resource Aspect

The lack training for production process in the studied area can be observed. In the availability of human resource dimension, $45.70 \%$ respondent state that human resource is not available; in the low cost human resource dimension, $35.60 \%$ respondents state that the human resource cost them low sums of money, while the rest state that they spend high sums of money on human resource. Lastly, $41.60 \%$ respondents state that their employee skills can be easily upgraded. Thus, we can sum that in human resource aspect, $40.90 \%$ of respondents agree that human resources in their industry is sufficient. This implies that this aspect has relatively low score, or there is a constraint to improve this aspect.

\section{c) Capital Aspect}

The capital aspect can be analyzed form several dimensions as well. The first dimension is the need of high capital, in which $54.60 \%$ respondents state that they do not need high capital. The next dimension is the availability of capital, in which $30.70 \%$ respondents agree that capital is widely available, and the rest state that capital is not widely available. The last dimension, the cost of capital (from debt), $40.70 \%$ respondent state that the cost of capital is affordable, while most of respondents state it is unaffordable.

\section{d) Technology Aspect}

This aspect related with the availability of alternative technology to support production process. On the production technology dimension, 52.60\% respondents think that their production technology is simple technology. On the availability of equipment dimension, $32.80 \%$ respondents think that the equipments are widely available, while the majority thinks that the equipments are hard to acquire. On the last dimension, production equipment price, $38.80 \%$ respondents state that the prices are affordable.

\section{2). Distribution Capacity}

The empowered level in production aspect is assessed from market coverage, ease in selling, and availability of distribution channel. Some of the craftsmen still sell their products around Surakarta and several nearby cities. Only few of products reach wider marketing coverage outside Surakarta area. This is reflected in only $34 \%$ respondents have marketing coverage up to provincial level, and it is not a continuous selling activity. Craftsmen still experience difficulties in term of marketing. Only 34\% respondents state that it is relatively easy for them to sell their products. Most of the craftsmen used direct selling as 
their distribution channel. Only $15 \%$ of the craftsmen have decent distribution channel.

\section{3). Market Demand Aspect}

This aspect is measured through market segment of handicrafts industry, production process to fulfill costumer's need, price competitiveness, and knowledge on market needs. The segment of handicraft market is consumer in middle and medium class which make $89 \%$ of producers aim for this segment. This shows low level of empowerment. While in term of production, most of the craftsmen produce their products on mass production or order based production.

The result of craftsmen empowerment level identification shows that only $24 \%$ respondents state that their product has competitive price. While on market needs dimension, respondents have relatively low information, with only 36\% of the respondents state that they have sufficient market needs information. From this description, we may conclude that the craftsmen have low empowerment level.

\section{4). Socio-Cultural Aspect}

The identification of empowerment level measured from socio-cultural aspect are showed through handicraft preservation indicator and participation level in the activities held by craftsmen association. From the identification result, we find that only $18 \%$ of respondents feel that it is easy to preserve their business tradition, while most of the respondents feel that preserving their business tradition is hard to do. On the other indicator, 38\% of respondents have been actively participated in the association activities. From this result we can conclude that the socio-cultural aspect has low score.

\section{5) The Intensity of Household Craftsmen Empowerment Service}

There is a need to conduct an analysis on the mentioned aspects to generate overview needed for formulating empowerment strategy. The improvement in household craftsmen performance depends on the accuracy and success of empowerment strategy. The model of empowerment for household craftsmen is formulated based on the result of empowered level analysis and Focus Group Discussion (FGD), conducted in three steps and involving academician, business practitioner, government, and the craftsmen. The empowerment model consists of production aspect, distribution aspect, market demand aspect, and sociocultural aspect. The model for each aspect can be explained through strategy, action, related parties, and prioritized objectives.

The intensity of service model reflects the craftsmen's responsiveness on the stimulus of empowerment model provided. This service model is expected to change craftsmen behavior in running their business (Bigsten, and Gebreeyesus, 2007). In this study, the intensity of service model will be provided for household craftsmen with an aim to develop their independency. The implementation of intensity model in 2017 to achieve the effectiveness of service model is as follows: 


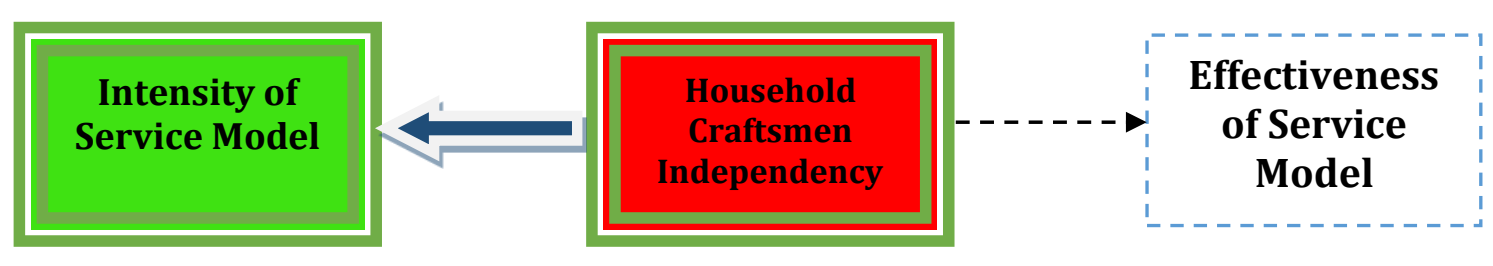

Figure 1.

Redesigned Intensity Model and Effectiveness Model

From the need assessment, we collect the basic data on the village's potency in the studied area, the supporting data for developing craftsmen's independency, and the prevalent number of SMEs. The Potency of Household Craftsmen Empowerment through Production Aspect.

We can describe the potency of household craftsmen empowerment through production aspect, the following explanation:

1. Strategic issue such as available raw materials, accurate distribution of capital aids, continuous production training and available alternative technology.

2. Act such as cooperation with raw materials producer in producing the raw materials, accurate distribution of capital in financial and non-financial form, financial management training for craftsmen and cooperation with academicians in product development.

3. Stakeholders such as government through SKPD, financial institution, university and private business and Non-Governmental Organization.

4. Short term conducting empowerment through: non-financial aids and legal protection, capital aids and CSR utilization, marketing and financial management training and developing cooperation in raw materials and community.

5. Long term conducting empowerment through: sustainable capital aids, increasing the cooperation in raw materials gradually, long term cooperation in marketing and financial management training and sustainable management and technology training.

We can describe the potency of household craftsmen empowerment through distribution aspect, the following explanation:

1. Strategic issue such as improving distribution system, promotion assistance, promotional media assistance and improving cooperation in distribution.

2. Act such as cooperation with modern shop, conduct an exhibition, provide information on market potency and create a cluster.

3. Stakeholders such as government, business consultant, university and companies and Non-governmental organization.

4. Short term conducting empowerment through: sales promotion assistance, conducting exhibition, protection from business competition and provide information on market potency.

5. Long term conducting empowerment through: assistance for sustainable promotion, conducting continued exhibition, protection from business competition and government aids in creating cluster. 
We can describe the potency of household craftsmen empowerment through market demand aspect, the following explanation:

1. Strategic issue such as mastery at the information on handicraft market, the ease in handicraft marketing channel, fulfill customer's need and certification of handicraft products.

2. Act such as providing market information, follow customer's need, encourage product usage and provide information on certification.

3. Stakeholders such as government, companies, university and Non-governmental organization.

4. Short term conducting empowerment through: developing product uniqueness, information on handicraft market, encourage handicraft product usage dan develop a center for handicraft product marketing

5. Long term conducting empowerment through: sustainable product design innovation, sustainable market information, sustainable product usage encouragement and develop a sustainable centre for marketing.

We can describe the potency of household craftsmen empowerment through sociocultural aspect, the following explanation:

1. Strategic issue such as conducive business climate, handicraft culture, inherited tradition and open job opportunity.

2. Act such as support from local government regulation, socialization of local government regulation, evaluation on local government assistance and attract people who are dropped out from school.

3. Stakeholders such as government, companies, university and Non-governmental organization.

4. Short term conducting empowerment through: support from local government, continuous protection from local government, handicraft as tradition and encouraging handicraft products culture.

5. Long term conducting empowerment through: sustainable support from local government, consistency in local government protection, sustainable handicraft culture and implementation of handicraft SMEs protection.

\section{CONCLUSION}

Based on the survey, we gathered the basic data on the potency of village in the studied area. The collected data related with the problems and supports in the implementation of craftsmen independency development through PNPM program as well as the prevalence number of SMEs through PNPM.

Based on the analysis result, we conclude that there is a need to formulate empowerment strategy to improve and develop handicraft industry. The validation on the empowerment model, which can be applied practically, is also needed, so that craftsmen's performance will increase. There is also a need of participation from various parties (academicians, businessmen, government, and nongovernmental organization) so that the empowerment program will be able to meet 
its objective. Further study is also needed to validate the model, so that it can be applied in handicraft business in particular and small business in general.

The redesigned model in implementing this study can be presented as follows

Figure 2: Inter-variable relationship and composite manifest

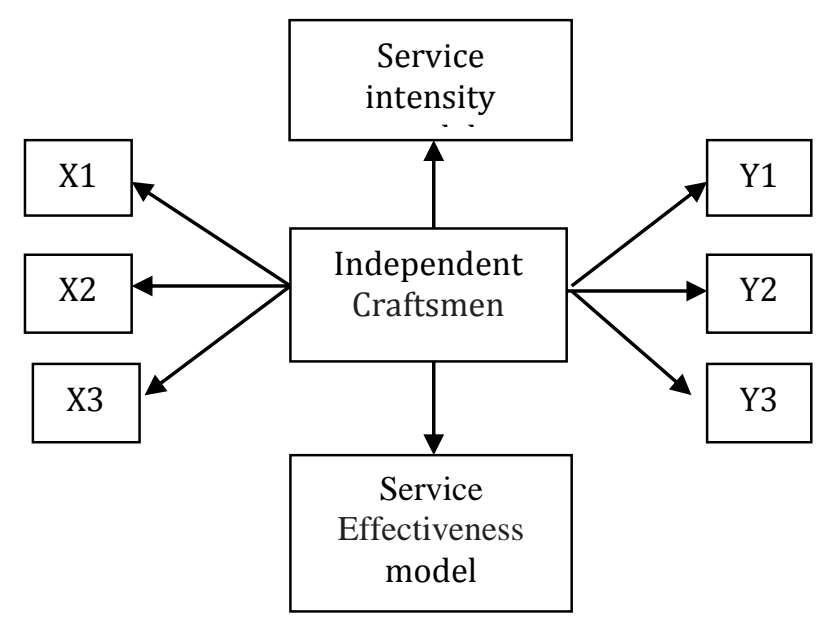

Notes:

$\mathrm{X} 1=$ Self motivation $(\mathrm{X} 1)$

$\mathrm{X} 2=$ Self confidence and initiative $(\mathrm{X} 2)$

$\mathrm{X} 3$ = Time management $(\mathrm{X} 3)$

$\mathrm{Y} 1=$ Capital (Y1)

$\mathrm{Y} 2$ = Training for household craftsmen (Y2)

$\mathrm{Y} 3$ = Government policy (Y3)

The next steps to be taken in redesigning the model are as follows:

1) Implementing the Service Intensity Model that has been formulated into empowerment service model, which is ready to be implemented in the household craftsmen in Surakarta.

2) Performing the Service Intensity Model to formulate the Service Intensity Model for learning guidelines aimed to achieve independency of household craftsmen in Surakarta.

3) Developing and determining Pilot Project household craftsmen for Banjarsari sub-district in Surakarta.

4) Performing an analysis related to the household craftsmen responses on the variables that will be developed in this study. The variables to be measured are self motivation, self confidence and initiative, time management, capital, training for household craftsmen, and government policy. Performing model testing for four months and monitoring during the testing. Factor analysis technique will be used to analyze the result. 


\section{REFERENCES}

Barrett, B. \& Usui, M. 2002. Local Agenda 21 in Japan: Transforming Local Environmental Governance. Local Environment. 7. 49-67.

Bigsten, A and M. Gebreeyesus. 2007. The Small, The Young, and The Productive: Determinants of Manufacturing Firm Growth in Ethiopia. Economic Development and Cultural Change. Vol. 55, No. 4. pp. 813-840.

Borg, W. R., \& Gall, M. D. 1989. Educational Research: an Introduction (5 $5^{\text {th }}$ ed.). White Plains, NY: Longman.

Chang, H.C. 2007. A Study on Basic Agricultural Extension Organizations Involving Taiwan's Rural Community Empowerment Program. Community Development Journal. 120, 312-329.

Diaz-Puente, J.M., Cazorla Montero, A., de los Rios Carmenado, I. 2009. Empowering Communities through Evaluation: Some Lessons from Rural Spain. Community Development Journal. Vol. 44. No. 1. pp. 53-67.

Ellinger, A.D. and Cseh, M. 2007. Contextual Factors Influencing The Facilitation of Others' Learning Through Everyday Work Experiences. Journal of Workplace Learning, Vol. 19 No. 7, pp. 435-452.

Hennink, M., Ndunge, K., Mara P., and Ravi, J., 2012. Defining Empowerment: Perspectives from International Development Organisations. Development in Practice. Vol 22. No 2. pp. $202-215$.

Hess, D., Rogovsky, N., Dunfee, T. 2002. The Next Wave of Corporate Community Involvement: Corporate Social Initiatives. California Management Review. 44 (2). pp. 110- 125.

Hui, M. K., K. Au, and H. Fock. 2004. Empowerment Effects across Cultures. Journal of International Business Studies. 35: 46-60.

Hurst, E., and A. Lusardi. 2004. Liquidity Constraints, Household Wealth, and Entrepreneurship. Journal of Political Economy. 112 (2). Pp. 319 - 347.

Hurst, E and B.W. Pugsley. 2011. What do Small Businesses Do? Brookings Papers on Economic Activity. (2):73-118.

Jones, J. 2004. Training and Development, and Business Growth: A Study of Australian Manufacturing Small-medium Sized Enterprises. Asia Pacific Journal of Human Resources, Vol. 42 No. 1, pp. 96-121.

Kabeer, N. 2001. Resources, Agency, Achievements: Reflections on The Measurement of Women's Empowerment. Discussing Women's Empowerment- Theory and Practice, Stockholm, Sweden: Sida.

Kotey, B. and Sheridan, A. 2004. Changing HRM Practices with Firm Growth. Journal of Small Business and Enterprise Development, Vol. 11 No. 4, pp. 474-485.

Laverack, G and Wallerstein, N. 2001. Measuring community empowerment: a fresh look at organizational domains. Health Promotion. International. 16, 179-185.

Marsick, V.J. 2009. Toward a Unifying Framework To Support Informal Learning Theory, Research And Practice. Journal of Workplace Learning. Vol. 21 No. 4. pp. 265-275.

Mazzarol, T. 2003. A Model of Small Business HR Growth Management. International Journal of Entrepreuneurial Behaviour \& Research, Vol. 9 No. 1, pp. 27-49.

Nelu Eugen Popescu. 2014. Entrepreneurship and SMEs Innovation in Romania. Procedia Economics and Finance. 16 ( 2014 ) 512 - 520. 
Rutherford, M.W., Buller, P.F. and McMullen, R. 2003, Human Resources Management Problems over The Life Cycle of Small to Medium-Sized Firms. Human Resource Management. Vol. 42. No. 4. pp. 321-335.

Saru, E. 2007. Organisational Learning and HRD: How Appropriate Are They For Small Firms?. Journal of European Industrial Training. Vol. 31 No. 1, pp. 36-51.

Tseng, S.C. 2009. Community Building in Taiwan. Walkers Cultural Enterprise Ltd. New Taipei City, Taiwan. 